\author{
Ольга Соколова \\ Институт языкознания РАН \\ olga.sokolova@iling-ran.ru \\ Olga Sokolova \\ Institute of Linguistics, Russian Academy of Sciences \\ olga.sokolova@iling-ran.ru
}

\title{
ИМПЕРАТИВ ДАЁШЬ КАК МАРКЕР ИНТЕНСИФИКАЦИИ ИЛЛОКУТИВНОЙ СИЛЫ В СОВЕТСКОМ ПОЛИТИЧЕСКОМ ДИСКУРСЕ 1
}

\author{
THE IMPERATIVE DAESH' AS A MARKER \\ OF INTENSIFICATION OF ILLOCUTIONARY FORCE \\ IN SOVIET POLITICAL DISCOURSE
}

\begin{abstract}
В статье рассматриваются семантические переходы и дискурсивные трансферы императива даёшь как в диахронии, так и на материале корпуса текстов конца 1910-х — начала 1930-х годов. Выявляется, что процесс грамматикализации, заданный десемантизацией императива дай/давай в диахронической перспективе, получил развитие в дальнейшей прагматикализации единицы даёшь, связанной с преодолением дескриптивных функций, повышением интенсивности иллокутивной силы и перформативного потенциала. Эти свойства императива даёшь анализируются в силу значимости единицы при формировании многочисленных лозунгов советского политического дискурса. «Лозунгообразующая» роль императива рассматривается в аспекте перехода этой единицы из «матросского», пролетарского языка в сферу широкого узуального употребления. Важную роль в этом трансфере сыграл авангардный художественный дискурс, авторы которого активно включали единицу в свои агитационно-поэтические тексты, раскрыв ее лингвокреативный потенциал и сделав ее «ядерным» императивом агитационно-политических текстов. Проведенный анализ позволил выявить механизмы языковой и дискурсивной креативности, заложенные в основу формирования «языка революции» в 1920-е годы, а также проследить последующую обратную тенденцию советского политического дискурса к стереотипизации и серийности.
\end{abstract}

Ключевые слова: советский политический дискурс, императивы, грамматикализация, иллокутивная сила, языковая и дискурсивная креативность, авангардная поэзия, агитация.

1 Исследование выполнено за счет гранта Российского научного фонда (проект №19-18-00040) в Институте языкознания РАН. 
The article deals with semantic changes and discourse transfers of the imperative daesh' in a case study of the late 1910s - early 1930s text corpus. In the process of the grammaticalization (also known as "grammaticization"), lexical word (the imperative day(te) 'give') is transformed into a grammar word, or function word, changing its distribution and function in the process (the imperatives day/davay 'let us' and daesh'). This imperative daesh' is the subject matter of our analysis because it overcame descriptive functions and increased the intensity of illocutionary force in the further process of grammaticalization. Numerous slogans of the late 1910s - early 1930s formed with the imperative daesh' highlighted the significant role of this unit in the creating of the Soviet language. The transfer of this unit from the "sailor", proletarian language to the sphere of wide common usage determines the "slogan-forming" role of the imperative. The avant-garde authors, which included the unit in their agitation and poetic texts, played an important role in this discourse transfer. The avant-garde artistic discourse allowed revealing linguistic and creative potential of the imperative daesh' and developed it as the key imperative of the Soviet political discourse. The analysis made it possible to identify the mechanisms of linguistic and discursive creativity that formed the basis for the creation of the "language of revolution" in the 1920s, as well as to trace the subsequent reverse tendency of the Soviet political discourse towards stereotyping and seriality.

Key words: Soviet political discourse, imperatives, grammaticalization, illocutionary forces, language and discourse creativity, avant-garde poetry, political agitation.

\section{1. Из истории вопроса}

Исторически, в старославянском языке существовали две формы повелительного наклонения: собственно императив (от лат. imperare 'приказывать') и оптатив (от лат. optare 'желать'), восходившие к праиндоевропейской системе наклонений. Обозначая структурно-семантические характеристики императива как формы индоевропейского ирреального наклонения, К. Г. Красухин отмечает функцию предписания, обращенного к слушателю: «в чистом виде оно подразумевает, что заявленный приказ или просьба должны быть приняты как руководство к действию»; соответственно, «типичным для повелительного наклонения является второе лицо как лицо обращения» (Красухин 2004: 228). Если императив обозначает повеление, требование осуществления действия, то оптатив выражает пожелание, призыв к действию, исполнение которого не несет обязательного характера. К императивам относились формы атематических глаголов, остальные относились к желательному наклонению. Однако в русском языке оптатив не выделился как самостоятельное наклонение $^{2}$, и показателем императива выступает 2-е л. ед. и мн. ч. с морфемой $-u(c м о т р-u)$, которая может выпадать для единственного числа $($ встань-ø), показателем множественного числа является аффикс $-m e$ (говори-те).

2 Хотя на современном этапе в лингвистике выделяется категория оптативности (или оптативной модальности), выражающая понятийное содержание желательности и формирующая основные коммуникативные типы предложений (повествовательный, вопросительный, побудительный и оптативный) (Алтабаева 2003). 
В современном русском языке только два нетематических глагола давать (дати) и есть (гсти) сохранили особую форму спряжения (в 1-м л.

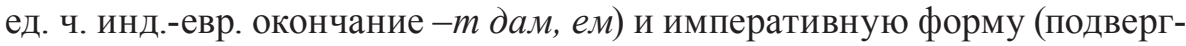
шиеся оглушению формы на -шь 2 л. ед. ч. дажь, гжь) (Савельева 2019: $92)^{3}$. Отмечая разные подходы к пониманию перформативной природы императивов, мы основываемся на расширенном понимании перформативности, заложенном в работах Л. Витгенштейна, а также учитываем коммуникативную установку императивов на каузацию адресата (о концепции императива как «перформативного каузатива» см. (Функционально-типологические аспекты 1990; Гусев 2005)). Таким образом, хотя императивы в целом обладают перформативной функцией, важно подчеркнуть, что уже исторически императив даёшь восходит к группе «истинных» императивов, обозначавших повеление и обладавших высокой степенью интенциональности и перформативности.

Помимо собственно императивной формы дай, входящей в парадигму глагола давать, в русском языке развилась форма «десемантизированного императива» дай/давай (Гусев 2005: 88). Такая форма не обозначает напрямую действие, которое должно быть совершено, но выполняет грамматическую функцию каузации (повеления): Давай пойдем, которое может быть выявлено из контекста: Купить еще сыра? - Давай. Давай в этой конструкции выступает как грамматикализованный показатель предложения или просьбы, «приказ не будет содержать давай» (Храковский, Володин 1986: 122). Эта форма используется для выражения побуждения к совместному действию, которое может реализовываться в конструкции давай(те) с инфинитивом глагола, выражающего действие: Давайте жить дружно! Давай также участвует в образовании гортатива, или «инклюзивного императива» (от лат. hortâri 'убеждать, побуждать'), разновидности императива, представляющей обращение к собеседнику с призывом совершить некоторое действие совместно: Давайте поднимем бокаль!!; Давайте споём эту песню! Важной здесь является именно семантика инклюзивности, выраженная в конструк-

3 Здесь, по всей вероятности, речь идет об одном из «косвенных» проявлений вторичной имперфективации (ср. глаголы дати - дајати - давати) и стяжения гласных (- $a a-$ в - $a-)$ в основе глаголов НСВ в старославянском языке, которое привело к смешению и некоторых форм глагола НСВ дајати (др.-рус. даяти), в котором вследствие утраты интервокального йота произошло слияние двух гласных -aa- в один простой гласный - $a$ - (дајати > даaти > дати), и форм нетематического глагола СВ дати, где произошла утрата формы 2. л. императива даждь (ср. «Отче нашъ, ..., хльбъ нашъ насущный даждь намъ днесь, ...»), вместо которой стала использоваться форма дай (ср. «застывший» оборот Дай Боже/ Богъ - Не дай Боже/ Богъ), отражающая первоначально старое видовое значение (вторичный имперфектив) и впоследствии получившая значение СВ. Такая трактовка поддерживается и аналогией старых императивных форм дай, дайте от утраченного с.-с. вторичного имперфектива дајати с формами знай, знайmе, а также аналогией формы знамь с формой дамь (ср. Маслов 1981: 280; ср. также: Белић 1999: 377-379). 
ции, когда давай сочетается с глаголом СВ мн. ч. 1-го л.: Давайте сделаем<вместе>.

Вторая форма, которая и является предметом нашего интереса, это императив даёшь. Он также относится к форме грамматикализованного императива, поскольку не указывает на действие 'давать', но несет иллокутивную функцию директива, предписывающего адресату совершить то или иное действие. Грамматически он выражается с помощью типичной формы 2-го л. ед. ч., но ее прагматическая функция связана с направленностью не на конкретного адресата, как в случае: (Петя), дай мне зубочистку, а на выражение директивной иллокутивной функции в речевом акте.

Согласно определению В. А. Плунгяна, грамматикализация «понимается как исторический процесс превращения неграмматической единицы языка в грамматическую - или появления у некоторой единицы языка большего числа грамматических свойств» (Плунгян 2011: 61). В русле теории Анны А. Зализняк, грамматикализация, являясь частным случаем семантического перехода, может реализовываться в форме разных типов: полисемии, семантической эволюции, когнатов и морфологической деривации (Зализняк 2013: 35). Грамматикализованная форма даёшь образуется по типу полисемического семантического перехода (ср. с приведенным у Анны А. Зализняк примером: фp. aller глагол 'идти' и вспомогательный глагол, образующий форму Futur immédiat (Там же)). Важное для нашего исследования развитие дополнительных коммуникативных функций отмечает Г. И. Кустова: такая единица, утратившая парадигматическое изменение и сформировавшая новые семантические связи, «продолжает осмысляться как глагольная, в значительной мере она превращается в служебную, только “служит” в коммуникативной сфере» (Кустова 2012: 354).

Если в случае десемантизированного императива дай/давай происходит грамматикализация знаменательной части речи ${ }^{4}$, то в случае императива даёшь можно говорить о дальнейшем развитии этого семантического перехода, основанного на интенсификации иллокутивной функции. Следуя теории речевых актов, можно разграничить форму дай/ давай как выражение речевого акта предложения или просьбы, а даёшь - речевого акта призыва и приказа (Сёрль 1986). В соответствии с классификацией иллокутивных целей Дж. Сёрля и Д. Вандервекена, императив даёшь именует не директивную иллокутивную цель, направленную на то, чтобы «попытаться заставить кого-то другого (других) сделать нечто», а декларативную, состоящую в том, чтобы «изменить (внешний) мир посредством данного произнесения» (Сёрль, Ван-

4 О семантических переходах, связанных с тенденцией к «персонализации дискурса», выражающихся в десемантизации, декатегоризации и др. признаках грамматикализации см. (Heine 2003). 
дервекен 1986: 252-253). Такое определение «декларативной иллокутивной силы» перекликается с идеей революционизации языка К. Маркса, высказанной в последнем из «Тезисов о Фейербахе» (1845) как призыв к политическим действиям: «Философы лишь различным образом объясняли мир, но дело заключается в том, чтобы изменить его» (Маркс 1955: 4). Заложенные К. Марксом основания «языка революции» были направлены на активизацию общих механизмов, лежащих в основании тотального обновления - политического, социального и языкового. Мостом между марксистским преобразованием мира с помощью политических действий и деланием вещей с помощью слов в теории речевых актов (ср. с названием книги Дж. Остина How to Do Things with Word (1955)) становится парадоксальное переосмысление самой сущности значения слова как «его употребления в языке», заложенное в Философских исследованиях (1953) Л. Витгенштейна (2018: 43). Как известно, идеи Л. Витгенштейна повлияли на возникновение прагматически ориентированной теории речевых актов Дж. Остина и Дж. Сёрля и на исследования в области логического анализа языка Г. Райла, П. Стросона и др.

\section{2. Повышение иллокутивной силы высказывания в императивной коммуникативной ситуации}

Целью отправителя императивных высказываний является целенаправленная каузация, т. е. совершение речевых действий, направленных на изменение окружающей реальности. Но и роль адресата в императивной коммуникативной ситуации активизируется: статус пассивного слушателя меняется здесь в сторону активного со-участника. От адресата требуют совершения действия в качестве ответной реакции. И действия эти могут быть как речевыми, так и неречевыми. Так, реактивная реплика на требование Отвечайте за свои поступки! может быть как словом, так и делом.

Когда мы имеем дело с грамматикализованной единицей даёшь, перформативный потенциал высказывания повышается за счет непрямого указания на действие, которое должно быть совершено. В отличие, например, от военного приказа: Приказываю открыть огонь по врагу, в директивном речевом акте с даёшь совершаемое действие имплицируется. В перформативно заряженных военно-поэтических призывах 1920-х годов - «Марш Будённого» (1920), известный как «Марш красных кавалеристов», или «Коммуна у нас. В Варшаве тож...» (1920) В. Маяковского - требование конкретных действий заменяется имплицитным, абстрактным призывом: Даёшь Варшаву! Дай Берлин!

Можно отметить, что эта модель (даёшь + стратегический военный объект) оказалась продуктивной при формировании дальнейшей военной агитации: Даёшь Шанхай, даёшь Нанкин! (рис. 1). 


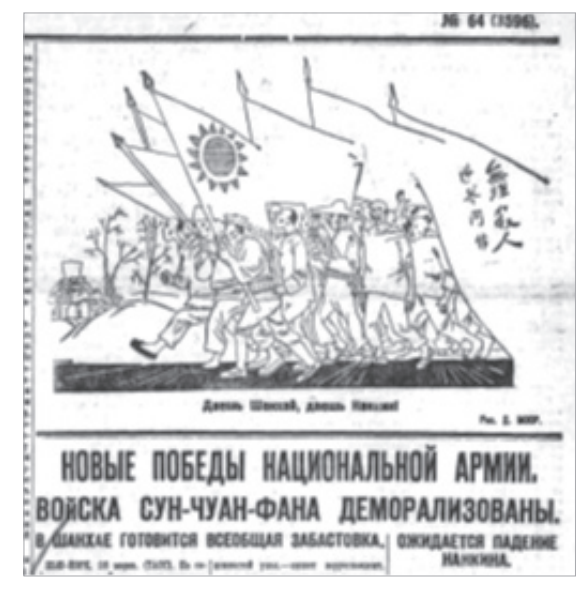

Рис. 1. Даёщь Шанхай, даёщь Нанкин! («Новые победы национальной армии. Войска Сун-чуан-фана деморализованы» Правда 64 (1927): 1)
За счет отказа от прямого называния действия бо́льшее значение обретает само речевое событие, а также повышается роль апеллятивной функции, оказывающей воздействие на адресата. Событие, которое разворачивается в императивной коммуникативной ситуации, не предполагает непосредственной и мгновенной реализации (в отличие от «собственно» императивов), но в этом и заключается иллокутивная сила воздействия такого высказывания. Во-первых, оно стимулирует адресата совершать не конкретные действия, а выступает триггером глубинных, когнитивных перемен.

Если взять пример из «Марша Будённого» или из Маяковского, то Bapmaва и Берлин здесь из индексальных знаков - точек на карте военных действий - переходят в статус знаков-символов, репрезентирующих Победу, воцарение Справедливости и наступление долгожданного Мира.

Во-вторых, в отличие от «прямого» императива, конструкция с даёшь выстраивается в иных темпоральных координатах. Приказ отдается здесь и сейчас, и требует немедленного выполнения, а призыв (например, Даёшь новый быт!) грамматически оформлен как событие в настоящем времени, но его прагматическая функция - активизация сознания адресата — не предполагает мгновенного разрушения старого и постройки нового быта. Поэтому и объекты, которые выступают в качестве пациенсов, претерпевающих изменения, обычно выражены абстрактными понятиями: Даёшь мировой Октябрь!; Даёшь восстание; Даёшь контакт! (Правда 34 (1924): 5)5. Сложно представить не ироническое употребление такой конструкции, включающей объект с конкретной семантикой: *Даёшь табуретку/букет тюльпанов. ${ }^{6}$ Такая императивная ситуация реферирует не к настоящему времени и даже не к ближайшему будущему, но к отдаленному будущему, находящемуся на неопределенной временной дистанции от ситуации говорения.

5 Здесь и далее ссылки на газету Правда даются по корпусу номеров с 1918-го до 1991-го года, указанному в списке литературы.

6 Хотя в период вхождения даёшь в узус и его активного употребления в 1920 1930-е годы возможности сочетаемости единицы были расширены, о чем будет сказано ниже: ср. «Заключительное слово даёшь» (пример из (Селищев 1928: 200)); «У дверей ресторана быв. “Прага” вывешен плакат: “Моссельпром - даёшь обед за 40 коп.”»; (Там же: 92); «Даёшь девчат» (Университетская правда 1 (1925)) (Там же: 98) и пр. 
Повышенная иллокутивная сила и перформативность высказывания, возможность активного имплицитного воздействия на адресата сделали даёшь чрезвычайно популярным императивом советской эпохи, одним из ключевых маркеров советского политического дискурса.

\section{3. Проблема языкового творчества в советском политическом дискурсе: от «революционизации» языка к серийной агитации}

Определяющая роль агитационно-пропагандистских языковых технологий при формировании советского дискурса осмыслялась уже на первых этапах его формирования. Трансформация социально-политической действительности приводит к «революционизации» языка и искусства, и к повышению градуса революционности. Это выражается в рефлексии опыта революции в работах теоретиков языка и в поиске нового языка на практике - как в поэзии, так и в теории языка и литературы, и в агитации. Проблема языкового творчества на пересечении разных типов дискурса - художественного, политического, агитационного и научного - получает разностороннее осмысление в работах формалистов ${ }^{7}$. Возможность множественных проекций: социальной революции - в область языкового новаторства, авангардных лингвистических технологий - в сферу политических практик, - становится активным живым процессом «контаминации дискурсов» и гибридизации новых медиа (Соколова 2016). Именно в этот период становятся особенно актуальны идеи языкового творчества В. фон Гумбольдта, согласно которым реализация «творческого процесса» осуществляется «духом народа» (Гумбольдт 1984). Революционные изменения в языке осмысляются лингвистами как «прорыв словарного языкового фронта» (Горнфельд 1922: 34) и «энергичная языковая деятельность» (Селищев 1928: 23).

Проблема трансфера языковых новаций между сближающимися дискурсивными практиками 8 осмысляется в работах формалистов. Открытия, сделанные на материале языка русского авангарда членами ОПОЯЗа (поэтическая функция языка и концепция поэтического языка как «высказывания с установкой на выражение» Р. О. Якобсона; приемы «остранения», «деавтоматизации» и «затрудненной формы» В. Б. Шкловского; ориентированность поэзии на «языковое новаторство» Г. О. Винокура и др.), осмысляются ими как инновационные технологии, направленные на создание нового «языка революции»9. Эти идеи распростра-

7 Об истории формирования и осмысления эстетических свойств языка художественной литературы и о развитии «лингвоэстетического подхода» в междискурсивном аспекте см. (Фещенко 2020).

8 О теории междискурсивных, межкультурных и концептуальных трансферов см. коллективную монографию (Лингвистика и семиотика культурных трансферов 2016).

9 О идеях «революции языка» и «языка революции» в литературе и лингвистике 1910-1920-х гг. см. (Фещенко 2018: 13-38; Калинин 2018). 
няются на политический и агитационно-пропагандистский дискурсы, например, в блоке статей «Лефа» 1924 года, теоретической проблемой которого становится художественное и революционное «устройство» языка Ленина (ср. с названиями статей в блоке: «Конструкция тезисов» Б. Томашевского; «Ленин, как деканонизатор» В. Шкловского; «Словарь Ленина-полемиста» Ю. Тынянова и др.).

Различные аспекты «советского политического дискурса» (далее СПД) (термин, утвердившийся в лингвистике в работе (Серио 1999)) как особого типа тоталитарного дискурса исследовался зарубежными и отечественными учеными: П. Серио (1994), Ф. Серсом (2004), А. Н. Барановым, Ю. Н. Карауловым (1994), Г. Гуссейновым (2002) и др.

Наиболее релевантным для нашего исследования является период конца 1910-х — начала 1930-х годов как этап формирования советского «новояза» и поле дискурсивного эксперимента по разработке новых технологий языкового воздействия. Важно подчеркнуть, что в отличие от слово- и языкотворчества футуристов 1910-х гг., когда основной целью разрушения языковой системы было создание нового языка - художественного, «вселенского», «универсального», - в 1920-е гг. кардинально меняется как цель, так и средства. Эксперимент в области языка искусства вышел за границы художественного дискурса, охватывая производство и быт, социум и политику. Произошла институционализация экспериментальных стратегий, что породило новые гибридные медиа: «роман-факт», «путьфильма», (физиологический / портретный / колхозный / производственный и др.) очерк, и т. д. Новаторство в области языка уступило место разработке технологий языкового воздействия как орудия политического дискурса. Установка на языковую креативность как тенденция к «созданию новых, уникальных языковых единиц и к модификации отношений между ними с целью кардинальной трансформации языковой системы и формирования нового языка» (Соколова 2020: 44-45) уступила место дискурсивной креативности, при которой средства интенсификации тех или иных языковых приемов направлены не на обновление языковой системы, а на достижение основных целей и задач конкретного дискурса ${ }^{10}$.

С дискурсивной точки зрения, динамика языкового творчества в СПД развивалась от лингвокреативного заряда, заложенного русским художественным авангардом и осознанного формалистами в понятиях «деавтоматизации» и «остранения», до стереотипности, клишированности, автоматизации. Такая динамика выразилась в том числе в выявленном П. Серио внутреннем противоречии СПД, идеологическая, коммуникативная и семантическая «двусмысленность» и «двойственность» которого проявилась в двух противоположных тенденциях: «деклариру-

10 Также о теоретических основаниях лингвокреативности см.: Демьянков 2009; Зыкова, Киосе 2020; Фещенко 2020 и др. 
емых гомогенностью, единством и монолитностью, с одной стороны, и лежащей в основе его неоднородностью — с другой» (Серио 1999: 381)11.

Если основным объектом исследования СПД в работе П. Серио стали номинализации, то мы обратимся к другому важному маркеру языковой манипуляции как ключевой компоненты советского политического дискурса - к императивам. Интерес к этим единицам, обладающим перформативной функцией, связан с повышенной частотностью их употребления в агитационном дискурсе 1920-1930-х гг.

Помимо императивов к основным «лозунгообразующим» единицам относятся также долой, nycmb, да здравствует и некоторые другие: Долой солому!; Долой воров-спекулянтов! (Беднота янв. (1921)); Долой фракиионность (заглавие брошюры, Москва, 1924) (цит. по (Селищев 1928: 132)); Долой самодержавие!; Долой монархию!; Долой царя!; <аббревиатура> ОДН - Общество "Долой неграмотность»; Долой северную военщину! (Правда 100 (1926): 7); «Организуйтесь, товарищи! Пусть крепнет и растет организованный пролетариат» (Прокламация) (цит. по (Там же: 28)); Пусть киевские рабочие вместе с рабочими всего мира подсчитают свои силь (Прокламация) (цит. по (Там же: 130)); Пусть живет в веках дело великого Ленина; Да здравствует гений всемирных чудес - могучий творческий труд!; Да здравствует 1-ое мая!.. (супрематический плакат); Да здравствует свобода!; Да здравствует международное братство трудящихся! Да здравствует штаб мировой революичи - Коммунистический Интернациионал! Да здравствуй первое мая - праздник труда! (Приказ революционного военного совета СССР. 1 мая 1926 г. №240. Гор. Москва» (Правда 100 (1926): 1)12; Да здравствует советская республика! Да здравствует объединение рабочих всего мира! (Там же: 7); Да здравствует сплоченность стальных ленинских рядов! Да здравствует стальное единство нашей партии! (Там же 5 (1926): 6). Отдельно можно выделить устойчивые оппозиции долой - даёшь: Долой учебу — даёшь работу или производство (Красная Молодежь 2 (1925) 123); Долой назначенство, даёшь выборных от народа (Октябрь 2 $<1920$-е>) (цит. по (Селищев 1928: 92)).

Поставленное на поток, серийное производство лозунгов в советском агитационном дискурсе влияло на адресата - народ, который также массово их воспроизводил: Тысячи рабочих отвечают на речь Життона возгласами: «Зашитим Советский Союз!», «Даёшь Советь в Париже!»,

11 Cp. с двусмысленностью (ambiguity) тоталитарного «новояза» Дж. Оруэлла, основанного на амбивалентности и энантиосемии, когда слова получают противоположное значение: «Война - это мир», или с высказыванием Н. Хомского о «двойной» интерпретации словосочетания rogue state - «обыденной» (англ. идиом. 'государство-изгой’) и «пропагандистской» (в политическом дискурсе США этим термином обозначаются страны, не находящиеся под их контролем) (Noam Chomsky 2001).

12 Здесь и далее в ссылках к источникам примеров из газеты «Правда» указывается название статьи, если оно имеет значение для проводимого анализа. 
«Освободите Марти!», «Да здравствует компартия!» (Правда 46 (1930): 2); Всем известно, в каком состоянии находились наши нефтеперегонные заводы. В течение ряда лет мы кричали: «даёшь добычу!», «даёшь бурение!», но не обращали должного внимания на нефтезаводы (Там же 291 (1927): 10). Сведение коммуникативной роли адресата к ретрансляции и бесконечному повтору инициальной реплики отправителя, в роли которого мог выступать как конкретный автор, так и абстрактный, «универсальный» субъект ${ }^{13}$, является характерной чертой тоталитарного дискурса. При этом воспроизводимые «адресатом-ретранслятором» реактивные реплики обретают форму гула, переходя в «агит-глоссолалию»: В речи некоторых рабочих объединились в одно сложное сочетание вводные слова «ясно», «определенно» и другие. - Это ясно-определенно; «Конешно-вопще, именно-так-сказать»; «конешно так сказать вопще даёшь и больше ничего» (в речи женщины-делегатки) (цит. по (Селищев 1928: 204)).

\section{4. Коммуникативные роли в императивной речевой ситуации: даёшь действия речевые и неречевые}

С точки зрения коммуникативных ролей, можно разграничить следующие императивные ситуации для «собственно» императива и дай/ давай(те)-императива: в «собственно» императивной форме адресата, который является исполнителем, побуждают совершить определенное действие: Дай лапу. Форма с десемантизированным императивом дай/ давай выражает предложение или просьбу, обращенную к адресату, который часто может совпадать с адресантом: Давай(те) построим Вавилонскую башню.

Даёшь-императив выражает направленность сообщения не на конкретного адресата во 2-м л. ед. ч., ср. *(Коля), даёшь стакан воды, а на коллективного адресата, часто обозначающего абстрактное множество и выраженного в ед.ч. Такой коллективный адресат может обозначать целый народ или даже общепланетарный социальный класс (пролетариев), номинация которого обладает значением собирательности: (Советский народ/Мировой пролетариат), даёшь мировую револючию.

Активизация иллокутивной функции у даёшь приводит к трансформации и коммуникативной модели, реализуемой с помощью этого императива. В конструкциях с даёшь, наиболее активно реализуемых в СПД, происходит двойной дейктический сдвиг. Во-первых, получатель сообщения здесь обозначает не конкретного адресата (mbl), а коллектив-

13 Подробнее об «адсубъективации» как «расщеплении», «дроблении» формысубъекта на две позиции: «ту, где произносится «я», где берется ответственность, hit et nunc, за высказывание, и ту, где находится «универсальный субъект» и занять которую может «кто угодно», любой» см. (Серио 1999: 369). 
ного, массового ( $(b l)$. Во-вторых, учитывая смену масштаба реализации коммуникативной ситуации с уровня локальной, частной коммуникативной ситуации на глобальный (даже международный, всемирный) уровень, даёшь предполагает обращение ко всем участникам коммуникации, включая как коллективного адресата, так и самого адресанта. Следуя предложенному Э. Бенвенистом разграничению инклюзивной и эксклюзивной форм на том основании, что «инклюзивная форма» $(я+b b l)^{14}$ осуществляет сочетание лиц, между которыми существует «корреляция субъективности», можно сделать вывод о том, что даёшь выступает прагма-

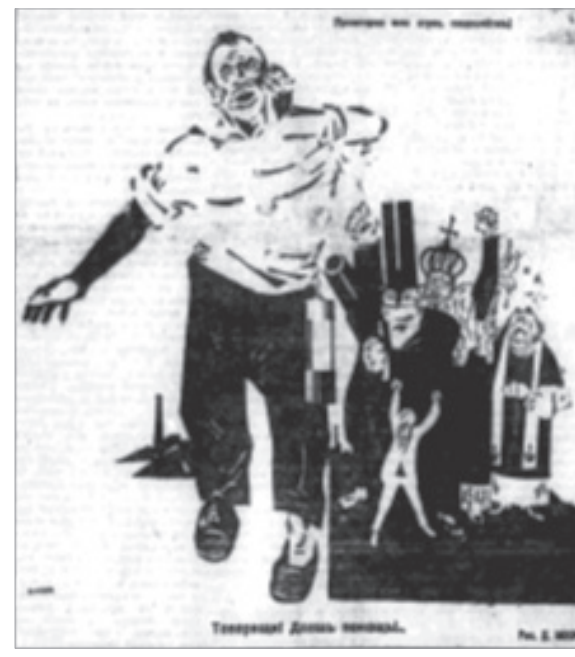

Рис. 2. Д. Моор. Пролетарии все стран, соединяйтесь! Товарищи! Даёшь помощь! (Правда 121 (1926): 1) тическим маркером инклюзивной формы $м ы л(я+8 b l)($ Бенвенист 1974: $267)^{15}$. Таким образом, коллективно адресованная императивная форма даёшь, включающая отравителя в область каузации, является выразителем инклюзивного значения, имплицитно объединяющего под общим инклюзивным МЫ максимально широкого, массового адресата (весь советский народ, мировой пролетариат).

Редукция дескриптивности (собственно императива) приводит к актуализации экспрессивной и апеллятивной функций в грамматикализованных формах. Повышенный перформативный потенциал таких императивов реализуется в ориентации на массового адресата как исполнителя, выраженного обобщенным лицом в ед. ч. или мн. ч.: Рабочий, даёшь паровоз! Крестьянин, даёшь фронту хлеб! (из лозунгов 19191921 гг.); Эй, молодежьь! Учебу даёшь!; Волховстой даёшь ток (1925) (цит. по (Селищев 1928: 97, 98)); Товарищи!! Даёшь помощьь... (см. рис. 2) (Правда 121 (1926): 1).

Однако по частотности употребления доминирует невыраженный адресат, эллипсис которого расширяет возможную целевую аудиторию: Даёшь Магнитку!; Даёшь смьчку с красноармейцуами (Известия 44 (1925)); Даёшь науку массам!; Даёшь избу-читальню! (Северньй Комсомолеч 1 (1925)); Даёшь сто прочентов попадания в цуель (Известия 135

14 Инклюзивная форма противопоставляется эксклюзивной, означающей «я + они» (Бенвенист 1974: 267).

15 Здесь можно говорить о наложении прагматической функции инклюзивного обращения, характерной для гортатива, типа: Давай споем!, которая формирует значение инклюзивности и для императива даёшь. 
(1925)); Даёшь технику (Там же 44 (1925)) (цит. по (Селищев 1928: 98); Даёшь пятилетку за четыре года!; Даёшь детскую пятилетку! (Правда 193 (1929): 5); Даёшь ток!; Пионеры <..> несли знамена с призывами и лозунгами, рожденными в недрах фабрик и заводов: Даёшь максимум производительности, кратчайшее покрытие третьего займа и полную боевую готовность рабочего класса и Красной армии (Там же 193 (1929): 1); Даёшь сочиализм! Даёшь бесклассовое соииалистическое общество! (Бурные, долго не смолкающие аплодисменты) (Там же 120 (1932): 3).

В случае, когда пациенс выражается конкретным понятием, оно реферирует не к определенному денотату, а к классу называемых предметов: Казармы хороши зимою. А летом...- Даёшь палатку! Даёшь поле! Даёшь реку! (Известия 135 (1925)); Даёшь рабоче-крестьянского стрелка. Даёшь комсомольиа-стрелка (Известия 115 (1925)); Даёшь грамоту. Даёшь букварь (Там же 295 (1924)) (цит. по (Селищев 1928: 98); на Сталинградском тракторном заводе издавалась газета «Даёшь трактор!» (лозунг на СталГРЭС); Даёшь комбайн! (лозунг на заводе комбайнов); Даёшь коммуниста! (Правда 271 (1923): 3); Даёшь плуг и культиватор! (Там же 86 (1926): 5); Даёшь землемера! (Там же 70 (1926): 2); Даёшь парт'ячейку! (Там же 108 (1925): 5); Даёшь винтовку и тир! Даёшь кружки всесторонней военной подготовки! (Там же 229 (1927): 3) или выражается номинативными группами с указанием числа требуемых объектов: Даёшь 3.000 новых членов кооператива (Там же 178 (1924): 7). Также встречается метафорическое и метонимическое обозначение пациенса: Даёшь больше красных птии, даёшь больше крылатых бориов за коммунизм («Достроим самолет “Правда"»// Там же 160 (1923): 4); Рабочий Париж дает отпор антисоветской травле. Массовые митинги в рабочих районах. «Защитим советский союз! Даёшь Советы в Париже» (Там же 46 (1930): 2).

Употребление даёшь в инициальной и реактивной репликах позволяет говорить о расширении функций императива, добавлении фатической функции. Даёшь в 1920-е годы становится контактоустанавливающей единицей, своеобразным паролем-отзывом, маркирующим диалог посвященных в дело строительства новой советской реальности:

- И, показывая на широкий плакат у входа в фабрику, она [работнииа] повторила написанный там лозунг: "Даёшь 14 тысяя пудов пряжси в месяч!». А от себя прибавила: - Даёшь повышение производительности труда! — первомайский лозунг всех рабочих СССР. - Правильно!.. Даёшь!.. - загудела тысячная толпа первомайцев (Известия 101 (1925)) (цит. по (Селищев 1928: 98); «Даёшь трамвай!» Таким возгласом всегда встречают своего представителя в Моссовете рабочие и работниць кожевенного завода Штейнберга (Правда 271 (1923): 4).

Такие имплицитные формы выражения повелительности (в форме изъявительного наклонения) и множественной адресации - массовой и гортативной (в форме ед. ч.) - можно обозначить как инвазивные еди- 
ницы. Развивая концепцию Дж. Сёрля и Д. Вандервекена, можно сделать вывод, что такие единицы обладают повышенной «интенсивностью» иллокутивной силы, обусловленной корреляцией имплицитности выражения и заданными критериями иллокутивной «интенсивности» (включающими иллокутивную цель, коммуникативную ситуацию, условия пропозиционального содержания и др. (см. Сёрль, Вандервекен 1986: 261-262)). Манипулятивный эффект здесь реализуется через многоуровневое и многовекторное преодоление таких коммуникативных помех, как дистанцированность, затрудненность воздействия на массового адресата, а также возможное неприятие с его стороны. В конструкции с даёшь происходит повышение интенсивности иллокутивной силы и перформативного потенциала.

\section{5. Междискурсивная природа даёшь: из «матросского языка» в язык поэзии и политики}

Помимо отмеченных специфических прагматических функций даёшь (особенности дейксиса и выражение инклюзивности), эта единица также маркирует характерную для формирования советского новояза междискурсивность. Специалист по языку революционной эпохи А. М. Селищев в главе «Борьба, война и язык», посвященной вхождению военных терминов в язык революционной и советской эпохи, отдельно выделяет единицы, источником которых стал «матросский язык»: держать курс на и даёшь: Ветер крепчал. Волны седели, и бились свирепо плашкоуты (баржи) о борта парохода. Еще несколько минут. Ветер обрывками несет, команду: - Крепить тросьь! Чаль к берегу! Карбас, карбас даёшь! (Правда 183 (1925)); «Даёшь!» И тут такое было... «Топи их, братиьн... Все одно!..» (Красный флот. Библиотека «Крокодила» 6-7) (цит. по (Селищев 1928: 91)).

Обращение к словарям позволяет выявить разговорно-просторечные истоки единицы даёшь: Даёшь (кого, что) 'В просторечии. Призыв энергично добиваться того, что выражено дополнением. Лучиим подарком для Красной Армии в целом, лучшим ознаменованием годовщины славной Конной Армии было бы принятие и воплощение в жизнь лозунга: «Даёшь коня». Фрунзе, Даёшь коня' (ССРЛЯ 1954: 524). Интересно отметить, что и в БТС (2000) просторечное значение даёшь также фиксировано, но уже в «заромбовой» зоне (фразеологические обороты, устойчивые сочетания слов) и с социально-агитационными, а не политическими примерами: ‘ $\diamond$ Даёшь! В первые годы Советской власти: призыв к осуществлению, преодолению чего-л. Д. стометровку! Д. миллион кубометров дров!' (БТС 2000: 237).

Прагматическое перефокусирование даёшь, сдвиг от дескриптивности в сторону активизации экспрессивной и апеллятивной функций, и дальнейшее повышение перформативного потенциала этого импера- 
тива, направленного на каузацию самого широкого массового адресата, начинается в период революционного обновления языка. Язык революции, гражданской войны, «матросский язык» в 1917-1918-х годах входит в самый широкий обиход, формируя обыденный дискурс. Семантический переход и грамматические изменения происходят в результате трансфера этого «флотского командного термина» в язык самых разных слоев населения как «чрезвычайно интенсивного» призыва (Селищев 1928: 91). В начале 1920-х происходит «легализация» единицы даёшь, которая из области ненормативной лексики переходит не только в разговорную речь, но и становится ядерным императивом эпохи - ключевым маркером советского политического дискурса.

Первые примеры просторечного употребления даёшь в реактивной форме ответа военных (матросов, красноармейцев) на политических митингах уже в 1918-м году подтверждает гипотезу дискурсивного трансфера этого императива как общего механизма формирования языка революции: Второй раз с Владимиром Ильичом мы встретились в августе 1918 года <..> - Но разве рабочие и деревенская беднота с этим согласятся? - говорил Ленин. - мне кажется нет <..> Знаю, вам воевать надоело, вы уже испьтали все «прелести» войны. Так как же быть? / Мы как один все встали и заявили: - Даёшь фронт, смерть буржуазии! (1918) (Памятные минуты 1969: 17); Забормотали ребята: не дезертиры мы, даёшь занятия, а то в город даёшь, не сидеть приехали, хлопочи; Ребята опять в хай: «Что за чорт: московской комиссии хороши были, а тут - на тебе. Даёшь представителя комсомола в комиссию» (Смена 6 (1924) (цит. по: Селищев 1928: 91)); Сама трансферная, междискурсивная природа этого императива становится объектом осмысления носителей: Mbl принесли с фронтов не только жадность $\kappa$ жизни, стихийный порыв к новому, но и полную уверенность, что вершины социалистической культуры мы возьмем таким же итурмом, каким брали Перекоп. И с тем же боевым кличем - «даёшь!» (Костерин 1963: 203)

Вхождение этого просторечного, табуированного императива в широкий оборот происходит параллельно в поэтическом и в политическом дискурсах. Ориентация на апроприацию коммуникативных стратегий и языковых технологий «пролетарского» языка выражается в контаминации авангардного художественного и политического типов дискурса. Частотное употребление даёшь в гибридных агитационно-политических текстах позволяет сделать вывод о значимой роли авангардных поэтов в создании «языка революции» на первых этапах формирования СПД. Первые употребления даёшь в поэзии встречаются уже в 1919-м году и частотность их повышается в начале 1920-х годов: Солнцеем души серебря, /Наши силь льются: /Паровозы Октября/Гоним Револющии. / Даёшь работу! По «Ноту»! (1919) (Каменский 1966: 114); Коммуна у нас. В Варшаве тож/верши по красному праву. / Даёшь/Варшаву! (1920) 
(Маяковский 1961: 143); Ухая, охая, ахая, всей братвой/Поставили поваленный поезд, / На пути - катись. / И радостно говорим все сразу: есть!/Рок, ульбку даёшь? (1921) (Хлебников 1996: 340); Даёшь!/ До мешков, /до запрятанных в сонные, /до сердиа/земного/лозунг долез. / Даёшь! / Грозою воль потрясенные, / трещат/казематы /над жилой желез (1923) (Маяковский 1957а: 156) и т. д.

Примерное время появления даёшь-лозунгов может быть выявлено из переписки Л. Сосновского и Л. Троцкого. Оно относится к 1918-1919-му годам - самой заре формирования СПД: По всем впечатлениям моим от газет и встреч нажим на середняка за редкими исключениями был поистине оголтелым, с потерей чувства меры. На него налетели с небывалым после 1918 - 19 годов шумом, проводя сразу 15 кампаний, и все кампании формулировались одним словом: даёшь... Даёшь хлеб, налог (до срока), страховку, ссуды, паевые, заем, самообложение, семфонд кажется, еще не все (Сосновский 1928: http). Сам Троцкий внес свой вклад в процесс формирования языка революции. В 1923 -м году он инициировал организацию «Общества друзей Воздушного флота» (ОДВФ) и сопутствующую ему крупную кампанию, название для которой было придумано самим председателем Реввоенсовета: Даёшь крылья! (1923). Еще один даёшь-лозунг в его соавторстве: Даёшь мотор! (Л. Троцкий, М. Черемных, 1923) был направлен на популяризацию и ускорение роста Авиационного моторостроения. Среди лозунгов этой кампании можно назвать метафорические призывы в названиях статей: «Даёшь воздух!» с подзаголовком «Жизнь воздушного флота в освещении Госкино» (Правда 160 (1923): 3).

В 1920-е годы даёшь входил в сводки лозунгов, которые списками топовых агиток регулярно печатались в газете «Правда»:

Зорко сторожите мирный труд рабочих и крестьян.

Не дремлет класовый враг. Держсите и вы порох сухим.

Если грянет буря, - будьте готовы!

Даёшь боевую мощь Советского Союза! (Там же 46 (1928): 1).

Взаимодействие обыденного и политического дискурсов выразилось в том числе в употреблении даёшь-императивов как фатических элементов, агитационных лозунгов и новых коммуникативных конструктов. В статье с названием «Пролетариат СССР заявляет о своей непреклонной решимости выполнить пятилетку в 4 года» императив означает не только призыв к действию, но и общее состояние умов, выполняя когнитивную функцию «императивного знания» советского человека:

- Даёшь пятилетку в четьре года!

- Через головы наймитов капитала - боевой привет пролетариям земного шара!

...бщцее настроение демонстрантов можсно выразить одной фразой: Даёшь пятилетку в четыре года! (Там же 260 (1929): 2). 


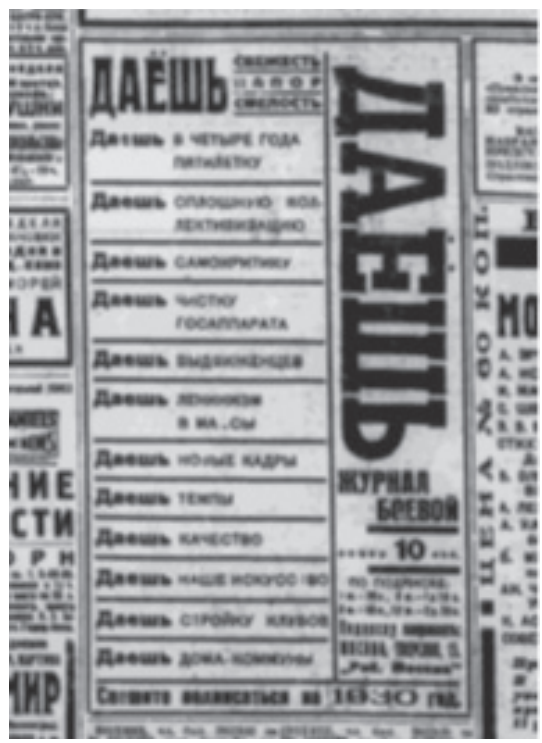

Рис. 3. Реклама в газете Правда (№ 306 (1929): 6)

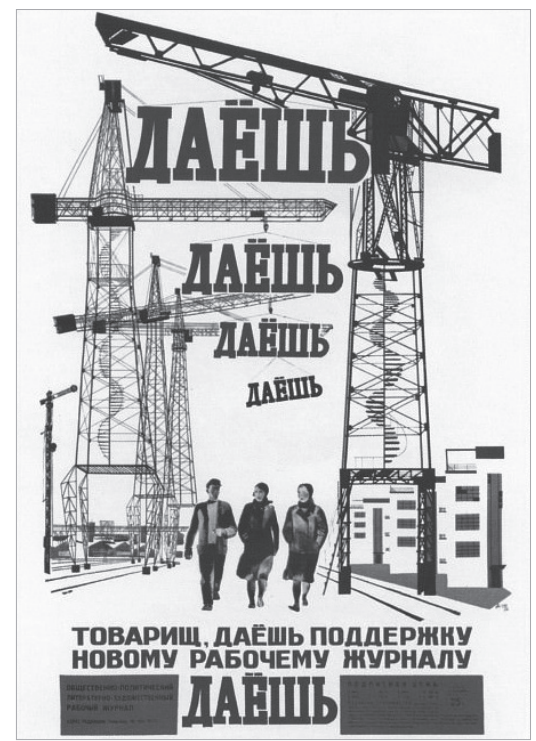

Рис. 4. А. Дейнека. Товарищ, даешь поддержку новому рабочему журналу «Даёшь». Плакат (1929)

В 1920-е годы даёшь стоит во главе самой масштабной агитации, формируя как отдельные лозунги, так и целые императивные серии, где валентность пациенса могла быть заполнена любым актуальным для повестки советского дня объектом: даёшь свежесть/напор/смелость/ Даёшь в четыре года пятилетку/Даёшь сплошную коллективизачию/ Даёшь самокритику <...> (Там же 306 (1929): 6). Любой объект становился компонентом директивного речевого акта (от крупного индустриализованного колхоза до хлеба): Даёшь крупный индустриализованный колхоз!; Даёшь хлеб, сырье для промышленности в три раза больще, чем mеперь! (Там же 103 (1928): 2).

Прием нанизывания объектов-пациенсов получил и графическую реализацию: в рекламе журнала «Даёшь» объекты перечисляются не линейно, через запятую, а вертикально, как строфоиды поэтического текста или кадры видео-хроники (рис. 3). На рекламном плакате А. Дейнеки ( мом подъемных кранов, которые служат для перемещения императива как ценного идеологического груза. Предложенное конструктивное исполнение сочетает в себе несколько медиа-режимов: даёшь как медиум идеологических установок в ситуации массовой коммуникации и краны как медиум пространственного перемещения лозунга по всей стране и далее - в отдаленную перспективу. Повтор даёшь создает эффект гиперболизации призыва, единица распадается на компоненты: повто- 
ряющееся $\partial a-\partial a-\partial a-\partial a$, что активизирует не только экспрессивную функцию, но и повышает перформативный эффект, поскольку соответствует диалоговому режиму актуальной коммуникации. Такое совмещение лингвистических, производственных и технических приемов соответствует идеям жизнестроения 1920-30-х годов Н. Чужака, С. Третьякова, Б. Арватова и принципу лингвосоциальной инженерии.

Многочисленные повторы императива и требуемых к выполнению объектов смещают границы между императивным наклонением, соотносимым с будущим временем, и объективной модальностью внеязыковой действительности. Заложенное в грамматикализованном императиве смещение (между грамматической формой и прагматиче-

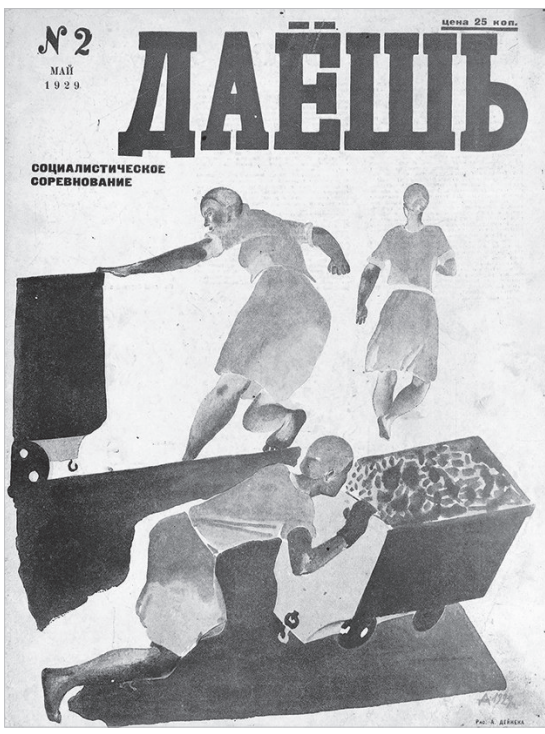

Рис. 4. А. Дейнека. Даёшь [Социалистическое соревнование]. Общественно-политический и литературно-художественный рабочий журнал (№ 2, 1929) ской функцией) приводит к дейктическому сдвигу по темпоральной оси: граница между отдаленным будущим и реальным настоящим стирается. Мелькающий вокруг адресата контрапункт даёшь + оказывает дополнительное воздействие, создавая эффект того, что все, к чему призывают лозунги, уже происходит здесь и сейчас, все это уже «дано»: и пятилетка за четыре года, и новый быт, и ленинизм в массы, и дома-коммуны.

В более поздний период 1920-х годов императив отрывается от конструкции даёшь +, став десемантизированным призывом к массам без каких-либо зависимых объектов и валентностей. Журнал с лаконичным названием «Даёшь», дизайн для некоторых номеров которого делали А. Родченко, А. Дейнека, Ф. Богородицкий и др., отражает популярность и действенность этого речевого акта в советское время. Хотя сам журнал носил однословное название: «Даёшь. Общественно-политический и литературно-художественный рабочий журнал», отдельные его выпуски посвящались острым проблемам современности: «Даёшь социалистическое соревнование» (1929 № 2) (рис. 5); «Даёшь производство продуктов питания» (1929 № 5); «Даёшь зерновую фабрику» (1929 № 10) и др.

Следуя идее Р. О. Якобсона о том, что поэтическая функция может присутствовать в любом, не только поэтическом высказывании (Якобсон 1975), можно отметить, что междискурсивная природа даёшь проявилась в сближении поэтического и агитационного дискурсов. Выше мы уже отмечали графическую организацию серийных императивов с даёшь, 
близкую по оформлению вертикальному членению поэтического текста. Помимо графического оформления можно отметить и внутренний ритм, который задается множественным повтором даёшь в агитационном тексте. Так, «Лозунги к XV МЮД», списки которых печатались в газете Правда, включали троекратное даёшь, что создавало ритмический рисунок, организуя партитуру лозунга как перформативного поэтического высказывания, ориентированного на произнесение «во весь голос»:

24. Рабочая молодежь, даёшь месячный заработок на заем индустриализачии! Крестьянская молодежь, ни одного двора без облигаиии займа. Да здравствует третий заем индустриализации!

39. Трудяшаяся молодежь! На борьбу с неграмотностью и бескультурьем. Даёшь знания, даёшь науку, даёшь культурную революиию! (Правда 193 (1929): 3).

Такой повтор даёшь как внутренний ритмический и визуальный контрапункт текста был характерен для агитационно-поэтических текстов, что повлияло на политический язык. Например, финал стихотворения с говорящим названием «Даёшь» Маяковского: Уголь, /хлеба, / железо, / угун/даёшь! /Даёшь! /Даёшь! (1930) (Маяковский 1958: 123), который, вероятно, является одним из источников популярного лозунга Даёшь стране угля! (семантическая трансформация этого лозунга выразилась в абстрагировании от первичного значения 'добывать уголь' и в формировании вторичного значения 'совершить какой-либо неординарный поступок', употребляется как с положительными, так и с отрицательными коннотациями'). К экспрессивным средствам относится и троекратный рефрен Даёшь/Варшаву! или Даёшь/небо!:

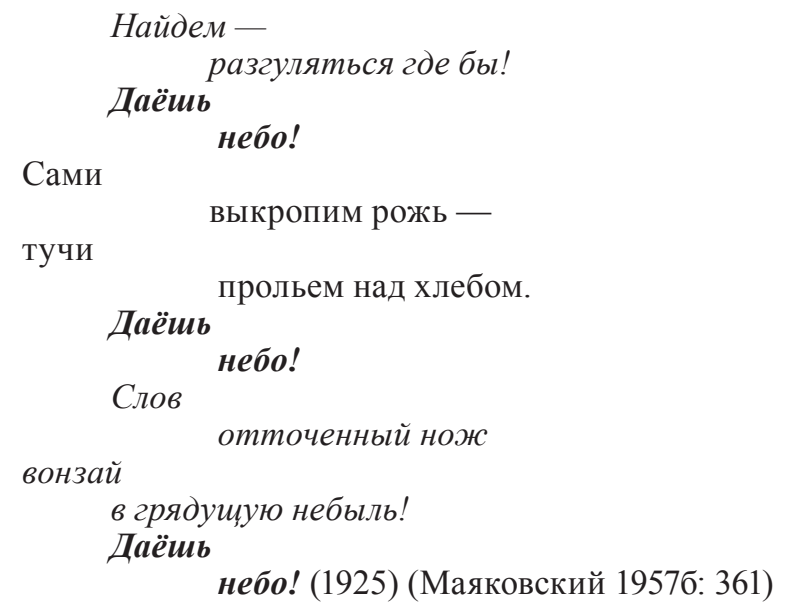

В междискурсивных текстах происходит наложение апеллятивноагитационной и поэтической функций, основным языковым средством выражения чего становятся такие инвазивные единицы, как даёшьимператив. 


\section{6. Поиск эквивалентов на других языках, или «вселенский язык» коммунизма}

Проблема создания «универсального» языка, значимая для авангардных поэтов, получила новый этап развития в 1920-е годы, когда язык революции должен был стать общим инструментов коммуникации для мирового пролетариата. Хотя сама утопическая идея «универсального языка» не реализовалась (ср. с наиболее систематизированными концепциями В. Хлебникова и Ю. Джоласа), интересно посмотреть, какие эквиваленты выбирались при переводе таких единиц советской агитации, как даёшь, образующих массовые лозунги ${ }^{16}$.

Отсутствие аналогов императивной конструкции с даёшь в других языках привело к поиску адекватных эквивалентов при переводе советских лозунгов. В словаре (Боянус, Мюллер 1935: 278) приводится перевод: let us have it!, который соответствует скорее десемантизированному императиву дай/давай, чем даешь. Еще менее удачным представляется перевод в (Квесевич-Сасина 2001: 110): 'прост. употр. как призыв к штурму, атаке, ударной работе и т. п. here we come!, here we go!'. Эти выражения относятся к более распространенным фразеологическим единицам и переводится обычно как 'вот', 'началось', 'поехали'.

В переводах лозунгов и плакатов 1920-1930-х годов выделяются такие средства, как междометия: Долой кухонное рабство! Даёшь новый быm (Г. Шегаль, 1931) 'Down with kitchen slavery. Hurrah for the new everyday life', и конструкции с императивом give us и let there be ...!; let (someone or something) be; let us, соответствующие императиву дай/ давай: Даёшь новую детскую книгу! 'Give us the new children's book!' (1925); Даёшь партию рабочего класса! 'Let there be a party of the working class'; Даёшь Комсомольск (1932) 'Let the city of Komsomolsk grow'; 'Let us miners mine more coal for our country'. Поставленная В. Мейерхольдом пьеса Д. Е. (аббревиатура «Даешь Европу!») по мотивам романа И. Эренбурга Трест Д. Е. История гибели Европы в одном из переводов звучит как "hand over Europe", видимо отсылая скорее к названию романа И. Эренбурга, чем пьесы В. Мейерхольда (“Trust, D. E., (the initials stand for "hand over Europe") (Rubenstein 1996: 91)).

Поиск по НКРЯ дал результаты перевода с помощью замены-комментария в английском языке: Проскочили первые cadbl, ворвались в центр, и страшное, жуткое, как смерть, «даёшь!» потрясло воздух [Н. А. Островский. Как закалялась сталь (ч. 1)] 'The mounted avalanche flashed by the gardens and poured into the centre of the city, and the air was rent by a fear-inspiring battle-cry as inexorable as death itself.' [Nikolai

16 Отметим, что с гортативом давай(те) переводческих проблем не было, поскольку подобные формы существуют и в других европейских языках (в германских, иберо-романских и др.): (англ.) Let + Pron. pl. Let us sing this song!; (порт.) конструкция vamos + inf., (исп.) vamos a inf и др. 
Ostrovsky. How the Steel was Tempered (pt 1) (R. Prokofieva, 1952)]; с помощью междометия - в немецком языке: Die Kavalleristen drangen durch die ersten Gärten, brachen ins Stadtzentrum ein, und der Ruf „Drauf und dran! ,erfüllte, grauenerregend wie der Tod selbst, die Luft. [Nikolai Ostrowski. Wie der Stahl gehärtet wurde (1. Teil) (3, 1936-1977)]; с помощью замены даёшь дискурсивной единицей в функции междометия - в английском языке: Откатываясь назад как волна от крутого берега отходили и снова бросались вперед со страшнымм: "Даёшь! “ [Н. А. Островский. Как закалялась сталь (ч. 1) (1930-1934)| Nikolai Ostrovsky. How the Steel was Tempered (pt 1) (R. Prokofieva, 1952)] 'As the ocean wave dashes itself against the rockbound shore, recedes and rushes on again, so they fell back only to press on again and again with awesome shouts of "Forward! Forward!"' (НКРЯ).

В более поздних переводах наблюдается тенденция отхода от калькирования и перевода даёшь с помощью грамматически далеких, но прагматически более соответствующих дискурсивных единиц (ср. с англ. now, итал. forza и др.). Более соответствующим по иллокутивной силе единице даёшь представляется вариант дискурсивного маркера now, который встречается при обратном переводе англоязычных лозунгов на русский язык: Democracy now! 'Даёшь демократию!'. Рассмотренные варианты позволяют сделать вывод, что перевод грамматикализованных, дискурсивных единиц является отдельной лингвистической проблемой и требует дальнейшего детального исследования.

\section{7. Трансформация функционирования даёшь в позднем советском дискурсе}

То, что императив даёшь стал ядерной лозунговой единицей эпохи 1920-30-х гг., видно из контекстов, в которых встречается этот лозунг в более поздние годы. Он становится маркером как повседневного общения, так и политического дискурса. Междискурсивное взаимодействие, в котором императив даёшь выполнял роль «инвазивного агента», проникающего между дискурсивными границами и формирующего СПД, хорошо видно из воспоминаний очевидцев эпохи. Так, Н. С. Хрущев в своих воспоминаниях под названием «Настойчиво овладевать знаниями, верно служить народу и делу коммунизма!» упоминает даёшь как императив, пришедший с поля боя в новую советскую реальность вместе с его носителями: Как я уже говорил, среди студентов того времени было много рабочих, преданных револючии, но не имевщих образования. Это были люди большой души, невероятной жадности к знаниям. Я с большим удовольствием вспоминаю это время. Это было замечательное время! Люди сели за парту, как бы при пистолете и шашке: слез с коня, сел за парту, взял сам карандаш и к профессорам - даёшь знания! Именно - даёшь, потому что тогда, я не скрою, был и са- 
ботаж. Некоторые преподаватели, особенно из среды враждебно настроенной интеллигенции, рассуждали так: чем хуже эти неучи-рабочие будут учиться, тем лучше для нас. (Веселое оживление в зале) (Правда 99 (1964): 1).

Безусловно, такое взаимодействие дискурсов было возможно именно на заре формирования СПД, в период утопической веры создателей языка революции (поэтов-авангардистов и революционных политиков) в «светлое будущее». Если в 1960-е годы утопический флер еще витал в Стране Советов, то в 1970-е эти междискурсивные связи были полностью разрушены, чему посвящено, в частности, антропологическое исследование Это было навсегда, пока не кончилось А. Юрчака (2014).

Что касается цитирования маркеров «романтических» постреволюционных лет, то оно стало носить «автоматизированный» характер. Статья под названием «Даёшь встречный!», описывающая, как с иенным почином выступили коллективы Северодонеикого и Рубежанского химических комбинатов < ..> (Правда 336 (1971): 1) получает ответ, отложенный на пять лет (что не имеет значения в условиях строительства мирового коммунизма): Рожденный в годы первых пятилеток патриотический призыв участников соревнования "Даёшь встречный!» сегодня, когда резко выросли масштабы нашей экономики, обогатился новым содержанием (“Встречный план предприятия”. Там же 152 (1976): 1). Отголоски этого «заветного» лозунга звучат и в поэзии 1950-1960-х годов: Сегодня вновь заветное - «даёшь!»/Звучит паролем радостного поиска (1950-е) (Ибряев http); Ты сильно его понимала, / тридиатых годов молодежь, /когда беззаветно орала /на митингах наших: "Даёшь!»<...> Наш поезд всё катит и катит, / с дороги его не свернешь, / и ночью горит на плакате/воскресшее слово - «Даёшь!» (1957) (Смеляков http); "Даёшь!» - надрываются глотки, / ВВеред!» - оглушает в ночи. / Буденовки, каски, пилотки.../И звезды на них горячи!/... Летит над полками бессмертье, /И году, как взятый редут, -/Двадиатый, лихой сорок третий -/С гвардейиами рядом идут (Кулаков 1969: 7).

Трансформация прагматического функционирования даёшь происходит в результате наложения метаязыковой функции, выраженной с помощью кавычек и других маркеров цитирования. Употребление даёшь в конструкциях с непрямой речью, как безавторских цитат, приводит к утрате апеллятивной функции и иллокутивной силы императива, который превращается в рудимент языка ушедшей эпохи.

\section{8. Заключение}

Исследование семантических и прагматических трансформаций императива даёшь на этапе формирования «языка революции» позволяет сделать вывод о значимости этой единицы для образования советского агитационного и политического дискурсов. Рассмотрение динамики 
прагматического функционирования даёшь отражает модификацию основных механизмов художественных и политических практик этого времени. Междискурсивный трансфер единицы из «матросского», пролетарского, обыденного языка в общеязыковой узус происходит посредством адаптации даёшь в гибридных агитационно-поэтических текстах авангардных поэтов и способствует дальнейшему более активному вхождению императива в политический дискурс. Таким образом, именно в горниле междискурсивного творчества литературного авангарда конца 1910-х — начала 1920-х годов формируется «язык революции». На материале более поздних текстов отмечается уход от лингвокреативного модуса, заданного в авангардном творчестве, и дальнейшая тенденция к стереотипизации, повторяемости даёшь, ставшего частью многочисленных советских лозунгов. «Институционализация» этого разговорно-пролетарского и агитационно-поэтического императива проявилась в его переходе из категории декларативных речевых актов в категорию языковых клише, в стереотипизации, сопровождающейся уходом от речевого режима высказывания в режим вторичной цитации и сменой коммуникативной модели.

Таким образом, в диахронии происходит несколько прагматических «сдвигов» единицы даёшь: в сторону грамматикализации единицы в современном русском языке и далее - ее прагматикализации как императива с повышенной интенсивностью иллокутивной силы, что однако завершается переводом в категорию иллокутивно-нейтральных цитат в позднесоветский период. С коммуникативной точки зрения, лингвокреативный потенциал, заданный авангардным поэтическим дискурсом, выразился в раскрытии потенциала инклюзивного побуждения (ср. с гортативом), выражении массовой адресации и дейктического сдвига в этой единице. Последний переход (во второй половине XX века) проявился в смене фокуса в сторону безавторского и безадресатного вторичного употребления.

Распространение и тотальное доминирование даёшь как «ядерной» лозунговой единицы эпохи отражает тоталитарный дискурсивный механизм перевода событий и объектов эмпирической реальности (будь то мировая револючия, крупный индустриализованный колхоз или хлеб) в разряд вербальных актов. Активное использование речевых действий заменяет внеязыковые объекты и события. В советском политическом дискурсе произошло смещение по референциальной линии в вербальную область. Однако в отличие от авангардного языка 1910 -х и языка революции начала 1920 -х годов основными чертами СПД становится двусмысленность, двойственность (ср. с концепцией Серио 1999), стереотипность и серийность высказываний. Чем больше информация имеет двусмысленную и имплицитную форму выражения, тем эксплицитнее становится власть тоталитарного языка. 


\section{ЛИТЕРАТУРА}

Алтабаева Елена. Категория оптативности в современном русском языке. Дис. ... докт. филол. наук. Москва, 2003.

Баранов Анатолий, Караулов Юрий. Словарь русских политических метафор. Москва: Помовский и партнеры, 1994.

Белић Александар. Изабрана дела. T. IV. Историја српског језика: Фонетика. Речи са деклинацијом. Речи са конјугацијом. Београд: Завод за уџбенике и наставна средства, 1999: 327-484 [Белић Александар. Историја српскохрватског језика. Књ. II. Св. 2. Речи с конјугацијом. Београд: Научна књига, 1973].

Бенвенист Эмиль. Общая лингвистика. Москва: Прогресс, 1974.

Бирюлин Леонид, Храковский Виктор (ред.). Функционально-типологические аспекть анализа императива. Москва: Институт языкознания АН СССР; Ленинград: Ленинградское отделение Института языкознания АН СССР, 1990.

Витгенштейн Людвиг. Философские исследования. Москва: АСТ, 2018.

Горнфельд Аркадий. Новые словечки и старые слова. Москва, 1922.

Гумбольдт Вильгельм фон. «О различии строения человеческих языков и его влиянии на духовное развитие человечества». Гумбольдт Вильгельм фон. Избранные труды по языкознанию. Москва: Прогресс, 1984.

Гусев Валентин. Типология спещиализированных глагольных форм императива. Дис. ... канд. филол. наук. Москва, 2005.

Гусейнов Гасан. Д. С. П. Советские идеологемы в новом русском дискурсе. Москва: Дом интеллектуальной книги, 2002.

Демьянков Валерий. «Языковое творчество и речевая креативность». Язык как медиатор между знанием и искусством: Сборник докладов Международного научного семинара. Москва, 2009: 11-19.

Зализняк Анна. «Семантический переход как объект типологии». Bопросы языкознания 2 (2013): 32-51.

Зыкова Ирина, Киосе Мария. «Параметризация лингвистической креативности в междискурсивном аспекте: кинодискурс vs. дискурс детской литературы». Bonpocbl когнитивной лингвистики 2 (2020): 26-40.

Ибряев Константин. «Товарищ Комсомол». URL: https://rustih.ru/konstantin-ibryaevtovarishh-komsomol

Калинин Илья. «Как сделан язык Ленина: материал истории и прием идеологии». Becmник Санкт-Петербургского университета. Язык и литература 15 (2018): 605-617.

Каменский Василий. Стихотворения и поэмы. Москва - Ленинград: Советский писатель, 1966.

Квеселевич Дмитрий, Сасина Валентина (ред.) Русско-английский словарь междометий. Москва: Астрель - АСТ, 2001.

Костерин Алексей. «“Слово должно сверкать”. Об Артеме Веселом». Новый мир 11 (1963): 203-205.

Красухин Константин. Ведение в индоевропейское языкознание. Москва: Academia, 2004.

Кузнецов Сергей (ред.). Большой толковый словарь русского языка (БТС). Санкт-Петербург: Норинт, 2014.

Кузнецов Сергей (ред.). Большой толковый словарь русского языка (БТС). Санкт-Петербург: Норинт, 2000.

Кулаков Александр. «Через время». Советский воин 12 (1969): 7.

Кустова Галина. «Об иллокутивной фразеологии». Смысль, тексты и другие захватывающие сюжеты. Сб. статей в честь 80-летия И. А. Мельчука. Москва: Языки славянской культуры, 2012: 349-366.

Маркс Карл. «Тезисы о Фейербахе». Маркс Карл, Энгельс Фридрих. Сочинения в 50 mомах. Т. 3. Москва: Издательство политической литературы, 1955: 1-4.

Маслов Юрий. Грамматика болгарского языка/Для студентов филол. фак. ун-тов. Москва: Высшая школа, 1981. 
Маяковский Владимир. Полное собрание сочинений. В 13 т. Москва: Гос. изд-во худож. лит., 1955-1961. Т. 10. 1958.

Маяковский Владимир. Полное собрание сочинений. В 13 т. Москва: Гос. изд-во худож. лит., 1955-1961. Т. 5. 1957a.

Маяковский Владимир. Полное собрание сочинений. В 13 т. Москва: Гос. изд-во худож. лит., 1955-1961. Т. 6. 19576.

Маяковский Владимир. Полное собрание сочинений. В 13 т. Москва: Гос. изд-во худож. лит., 1955-1961. Т. 13. 1961.

Мюллер Владимир, Боянус Семен. (ред.). Русско-английский словарь. Москва: Советская энциклопедия, 1935.

Национальный корпус русского языка (НКРЯ). URL: https://ruscorpora.ru/new/

«Памятные минуты. Рассказывает бывший кремлевский курсант Ф. Солодов». Сoветский воин 12 (1969): 17-18.

Плунгян Владимир. Введение в грамматическую семантику: грамматические значения и грамматические системы языков мира. Москва: Российский государственный гуманитарный университет, 2011.

Савельева Лидия. История русского языка: основы палеорусистики. Москва: Юрайт, 2019.

Селищев Афанасий. Язык революиионной эпохи. Из наблюдений над русским языком последних лет (1917-1926). Москва: Работник просвещения, 1928.

Серио Патрик. «Русский язык и анализ советского политического дискурса, анализ номинализаций». Квадратура смысла: Франиузская школа анализа дискурса. Под ред. П. Серио. Москва: Прогресс, 1999.

Сёрль Джон. «Классификация иллокутивных актов». Городецкий В. Ю. (ред.). Новое в зарубежной лингвистике. Выпуск XVII. Теория речевых актов. Москва: Прогресс, 1986: 170-194.

Сёрль Джон, Вандервекен Дэниел. «Основные понятия исчисления речевых актов». Петров В. В. (ред.). Новое в зарубежной лингвистике. Выпуск XVIII. Логический анализ естественного языка. Москва: Прогресс, 1986: 242-263.

Серс Филипп. Тоталитаризм и авангард. В преддверии запредельного. Москва: Прогресс - Традиция, 2004.

Словарь современного русского литературного языка в 17 m. (ССРЛЯ) Т. 3. Москва Ленинград: Издательство АН СССР, 1954.

Смеляков Ярослав. «Даёшь!» URL: https://www.litmir.me/br/?b=551463\&p=1

Соколова Ольга. «Гибридизация дискурсов: теоретические основания и типы междискурсивного взаимодействия». Фещенко Владимир (ред.). Лингвистика и семиотика культурных трансферов: методы, принцииы, технологии. Москва: Культурная революция, 2016: 308-333.

Соколова Ольга. «Поэзия, агитация и реклама в художественном авангарде 1910-х 1920-х годов: языковая и дискурсивная креативность». Зборник Матице српске за славистику 98 (2020): 41-67.

Сосновский Лев. «Четыре письма из ссылки». 1928. URL: http://az.lib.ru/s/sosnowskij_1_s/ text_1928_4_pisma_iz_ssylki.shtml

Фещенко Владимир (ред.). Лингвистика и семиотика культурных трансферов: методы, принципы, технологии. Москва: Культурная революция, 2016.

Фещенко Владимир. Литературный авангард на лингвистических поворотах. СанктПетербург: Издательство Европейского университета в Санкт-Петербурге, 2018.

Фещенко Владимир. Лингвоэстетический поворот в теории языка и художественном эксперименте. Дис. ... докт. фил. наук. Москва, 2020.

Хлебников Велимир. Творения. Москва: Советский писатель, 1986.

Храковский Виктор, Володин Александр. Семантика и типология императива: Русский императив. Ленинград: Наука, 1986.

Якобсон Роман. «Лингвистика и поэтика». Басин Е. Я., Поляков М. Я. (ред.). Структурализм: “за” и “против”. Москва: Прогресс, 1975: 193-231. 
Heine Bernd. "Grammaticalization". Joseph Brian \& Janda Richard (eds.). The Handbook of Historical Linguistics. Oxford: Blackwell Publishing, 2003: 575-601.

"Noam Chomsky interviewed by Christopher Gunness", Rogue States Draw the Usual Line, Agenda, May 2001. URL: http://www.chomsky.info/interviews/200105--.htm.

Rubenstein Joshua. Tangled Loyalties: The Life and Times of Ilya Ehrenburg. University of Virginia: I. B. Tauris, 1996.

\section{LITERATURE}

Altabaeva Elena. Kategoriya optativnosti v sovremennom russkom yazyke. Dis. ... dokt. filol. nauk. Moskva, 2003.

Baranov Anatolij, Karaulov Yurij. Slovar' russkih politicheskih metafor. Moskva: Pomovskij i partnery, 1994.

Belić Aleksandar. Izabrana dela. T. IV. Istorija srpskog jezika: Fonetika. Reči sa deklinacijom. Reči sa konjugacijom. Beograd: Zavod za uџbenike i nastavna sredstva, 1999: 327-484 [Belić Aleksandar. Istorija srpskohrvatskog jezika. Knj. II. Sv. 2. Reči s konjugacijom. Beograd: Naučna knjiga, 1973].

Benvenist Emil'. Obshchaya lingvistika. Moskva: Progress, 1974.

Biryulin Leonid, Hrakovskij Viktor (red.). Funkcional'no-tipologicheskie aspekty analiza imperativa. Moskva: Institut yazykoznaniya AN SSSR; Leningrad: Leningradskoe otdelenie Instituta yazykoznaniya AN SSSR, 1990.

Dem'yankov Valerij. «Yazykovoe tvorchestvo i rechevaya kreativnost'». Yazyk kak mediator mezhdu znaniem i iskusstvom: Sbornik dokladov Mezhdunarodnogo nauchnogo seminara. Moskva, 2009: 11-19.

Feshchenko Vladimir (red.). Lingvistika i semiotika kul'turnyh transferov: metody, principy, tekhnologii. Moskva: Kul'turnaya revolyuciya, 2016.

Feshchenko Vladimir. Literaturnyj avangard na lingvisticheskih povorotah. Sankt-Peterburg: Izdatel'stvo Evropejskogo universiteta v Sankt-Peterburge, 2018.

Feshchenko Vladimir. Lingvoesteticheskij povorot v teorii yazyka i hudozhestvennom eksperimente. Dis. ... dokt. fil. nauk. Moskva, 2020.

Gornfel'd Arkadij. Novye slovechki i starye slova. Moskva, 1922.

Gumbol'dt Vil'gel'm fon. «O razlichii stroeniya chelovecheskih yazykov i ego vliyanii na duhovnoe razvitie chelovechestva». Gumbol'dt Vil'gel'm fon. Izbrannye trudy po yazykoznaniyu. Moskva: Progress, 1984.

Gusev Valentin. Tipologiya specializirovannyh glagol'nyh form imperativa. Dis. ... kand. filol. nauk. Moskva, 2005.

Gusejnov Gasan. D.S.P. Sovetskie ideologemy v novom russkom diskurse. Moskva: Dom intellektual'noj knigi, 2002.

Heine Bernd. "Grammaticalization". Joseph B. D. \& Janda R. D. (ed.). The Handbook of Historical Linguistics. Oxford: Blackwell Publishing, 2003: 575-601.

Hlebnikov Velimir. Tvoreniya. Moskva: Sovetskij pisatel', 1986.

Hrakovskij Viktor, Volodin Aleksandr. Semantika i tipologiya imperativa: Russkij imperativ. Leningrad: Nauka, 1986.

Kuznecov Sergej (red.). Bol'shoj tolkovyj slovar' russkogo yazyka (BTS). Sankt-Peterburg: Norint, 2014.

Kuznecov Sergej (red.). Bol'shoj tolkovyj slovar' russkogo yazyka (BTS). Sankt-Peterburg: Norint, 2000.

Ibryaev Konstantin. «Tovarishch Komsomol». URL: https://rustih.ru/konstantin-ibryaevtovarishh-komsomol/

Kalinin Il'ya. «Kak sdelan yazyk Lenina: material istorii i priem ideologii». Vestnik SanktPeterburgskogo universiteta. Yazyk i literatura 15 (2018): 605-617.

Kamenskij Vasilij. Stihotvoreniya i poemy. Moskva-Leningrad: Sovetskij pisatel', 1966.

Kveselevich Dmitrij, Sasina Valentina (red.) Russko-anglijskij slovar' mezhdometij. Moskva: Astrel' - AST, 2001. 
Kosterin Aleksej. «"Slovo dolzhno sverkat”. Ob Arteme Veselom». Novyj mir 11 (1963): 203-205.

Krasuhin Konstantin. Vedenie v indoevropejskoe yazykoznanie. Moskva: Academia, 2004.

Kulakov Aleksandr. «Cherez vremya». Sovetskij voin 12 (1969): 7.

Kustova Galina. «Ob illokutivnoj frazeologii». Smysly, teksty i drugie zahvatyvayushchie syuzhety. Sb. statej v chest' 80-letiya I.A. Mel'chuka. Moskva: Yazyki slavyanskoj kul'tury, 2012: 349-366.

Marks Karl. «Tezisy o Fejerbahe». Marks Karl, Engel's Fridrih. Sochineniya. V 50 tomah. T. 3. Moskva: Izdatel'stvo politicheskoj literatury, 1955: 1-4.

Maslov Yurij. Grammatika bolgarskogo yazyka/Dlya studentov filol. fak. un-tov. Moskva: Vysshaya shkola, 1981.

Mayakovskij Vladimir. Polnoe sobranie sochinenij. V 13 t. Moskva: Gos. izd-vo hudozh. lit., 1955-1961. T. 10. 1958.

Mayakovskij Vladimir. Polnoe sobranie sochinenij. V 13 t. Moskva: Gos. izd-vo hudozh. lit., 1955-1961. T. 5. 1957a.

Mayakovskij Vladimir. Polnoe sobranie sochinenij. V 13 t. Moskva: Gos. izd-vo hudozh. lit., 1955-1961. T. 6. 1957b.

Mayakovskij Vladimir. Polnoe sobranie sochinenij. V 13 t. Moskva: Gos. izd-vo hudozh. lit., 1955-1961. T. 13. 1961.

Myuller Vladimir, Boyanus Semen (red.). Russko-anglijskij slovar'. Moskva: Sovetskaya enciklopediya, 1935.

Nacional'nyj korpus russkogo yazyka (NKRYA). URL: https://ruscorpora.ru/new/

"Noam Chomsky interviewed by Christopher Gunness", Rogue States Draw the Usual Line, Agenda, May 2001. URL: http://www.chomsky.info/interviews/200105--.htm.

«Pamyatnye minuty. Rasskazyvaet byvshij kremlevskij kursant F. Solodov». Sovetskij voin 12 (1969): 17-18.

Plungyan Vladimir. Vvedenie v grammaticheskuyu semantiku: grammaticheskie znacheniya i grammaticheskie sistemy yazykov mira. Moskva: Rossijskij gosudarstvennyj gumanitarnyj universitet, 2011.

Rubenstein Joshua. Tangled Loyalties: The Life and Times of Ilya Ehrenburg. University of Virginia: I. B. Tauris, 1996.

Savel'eva Lidiya. Istoriya russkogo yazyka: osnovy paleorusistiki. Moskva: Yurajt, 2019.

Selishchev Afanasij. Yazyk revolyucionnoj epohi. Iz nablyudenij nad russkim yazykom poslednih let (1917-1926). Moskva: Rabotnik prosveshcheniya, 1928.

Serio Patrik. «Russkij yazyk i analiz sovetskogo politicheskogo diskursa, analiz nominalizacij». Serio P. (red.). Kvadratura smysla: Francuzskaya shkola analiza diskursa. Moskva: Progress, 1999.

Sers Filipp. Totalitarizm i avangard. V preddverii zapredel'nogo. Moskva: Progress — Tradiciya, 2004.

Slovar' sovremennogo russkogo literaturnogo yazyka. V 17 t. (SSRLYA) T. 3. Moskva Leningrad: Izdatel'stvo AN SSSR, 1954.

Smelyakov Yaroslav. «Dayosh'!» URL: https://www.litmir.me/br/?b=551463\&p=1

Sokolova Ol'ga. «Gibridizaciya diskursov: teoreticheskie osnovaniya i tipy mezhdiskursivnogo vzaimodejstviya». Feshchenko Vladimir (red.). Lingvistika i semiotika kul'turnyh transferov: metody, principy, tekhnologii. Moskva: Kul'turnaya revolyuciya, 2016: 308-333.

Sokolova Ol'ga. «Poeziya, agitaciya i reklama v hudozhestvennom avangarde 1910-h - 1920-h godov: yazykovaya i diskursivnaya kreativnost'». Zbornik Matice srpske za slavistiku 98 (2020): 41-67.

Sosnovskij Lev. «Chetyre pis'ma iz ssylki». 1928. URL: http://az.lib.ru/s/sosnowskij_1_s/ text_1928_4_pisma_iz_ssylki.shtml

Syorl' Dzhon. «Klassifikaciya illokutivnyh aktov». Gorodeckij V. Yu. (red.). Novoe v zarubezhnoj lingvistike. Vypusk XVII. Teoriya rechevyh aktov. Moskva: Progress, 1986: 170-194. 
Syorl' Dzhon, Vanderveken Deniel. «Osnovnye ponyatiya ischisleniya rechevyh aktov». Petrov V. V. (red.). Novoe v zarubezhnoj lingvistike. Vypusk XVIII. Logicheskij analiz estestvennogo yazyka. Moskva: Progress, 1986: 242-263.

Vitgenshtejn Lyudvig. Filosofskie issledovaniya. Moskva: AST, 2018.

Yakobson Roman. «Lingvistika i poetika». Basin E. Ya., Polyakov M. YA. (red.). Strukturalizm: «za» $i$ «protiv». Moskva: Progress, 1975: 193-231.

Zaliznyak Anna. «Semanticheskij perekhod kak ob"ekt tipologii». Voprosy yazykoznaniya 2 (2013): 32-51.

Zykova Irina, Kiose Mariya. «Parametrizaciya lingvisticheskoj kreativnosti v mezhdiskursivnom aspekte: kinodiskurs vs. diskurs detskoj literatury». Voprosy kognitivnoj lingvistiki 2 (2020): 26-40.

Олга Соколова

\author{
ИМПЕРАТИВ ДАЁШЬ КАО МАРКЕР \\ ИНТЕНЗИФИКАЦИЈЕ ИЛОКУТИВНЕ МОЋИ \\ У СОВЈЕТСКОМ ПОЛИТИЧКОМ ДИСКУРСУ
}

\title{
Резиме
}

У чланку се разматрају семантички прелази и дискурсивни преноси императива даёшь како у дијахронији, тако и на материјалу корпуса текстова с краја 1910-их — почетка 1930-их година. Отркивамо да се процес граматикализације, постављен десемантизацијом императива дай/давай у дијахронијској перспективи, развио у даљој прагматикализацији јединице даёшь, која је везана за савладавање дескриптивних функција, повећањем интензификације илокутивне моћи и перформативног потенцијала. Ова својства императива даёшь се анализирају на основу смисла јединице приликом формирања многобројних плаката совјетског политичког дискурса. „Плакатноградитељска" улога иператива разматра се у аспекту преласка ове јединице из „морнарског”, пролетерског језика у сферу широке општеприхваћене употребе. Важну улогу у овом преносу је имао авангардни уметнички дискурс, чији аутори су активно укључивали јединицу у своје агитационо-песничке текстове, откривајући њен лингвокреативни потенцијал и учинивши је „суштинским” императивом агитационо-политичких текстова. Спроведена анализа допушта откривање механизама језичке и дискурсивне креативности, који су у основи ,језика револуције” 1920-их година, као и проучавање касније обрнуте тенденције ка стереотипизацији и серијској производњи совјетског политичког дискурса.

Кључне речи: совјетски политички дискурс, императиви, граматикализација, илокутивна моћ, језичка и дискурсивна креативност, авангардна поезија, агитација. 